Scientia Marina 71(1)

March 2007, 145-151, Barcelona (Spain)

ISSN: 0214-8358

\title{
Reproductive biology of the striped goby, Gobius vittatus (Gobiidae) in the northern Adriatic Sea
}

\author{
MARCELO KOVAČIĆ \\ Prirodoslovni muzej Rijeka, Lorenzov prolaz 1, HR-51000 Rijeka, Croatia. E-mail: Marcelo.Kovacic@public.srce.hr
}

\begin{abstract}
SUMMARY: The striped goby, Gobius vittatus Vinciguerra, 1883 is a Mediterranean gobiid species considered to be rare and lacking in data on its reproduction. Sex ratio, length and age at first maturity, annual cycle of gonad development, spawning period and fecundity of G. vittatus were studied on 704 specimens collected by SCUBA diving in the northern Adriatic Sea (Kvarner area) from April 2001 to March 2002. The monthly sex ratio did not differ significantly, except during the spawning season, when it was strongly biased in favour of females. The estimated length at first maturity was 32.8 and 35.4 $\mathrm{mm}$ for females and males, respectively. In both sexes gonad development started in the first year of life. All specimens were mature by the third year. The spawning season was from April to July. Total fecundity ranged from 560 to 3045, with an average of $1426 \pm 89$ ripe eggs/fish. The simultaneous presence of three clearly distinct sizes of oocytes in ripe ovaries indicate that this species is a multiple spawner.
\end{abstract}

Keywords: Gobiidae, sex ratio, maturity, spawning, fecundity.

RESUMEN: BIOLOGÍA REPROdUCTIVA DE Gobius VITTATUs (GoBIIDAE) EN EL NORTE DEL MAR AdRIÁTICO. - El góbido listado, Gobius vittatus Vinciguerra, 1883 es una especie mediterránea considerada rara de la que se desconoce todo sobre su reproducción. En este estudio se han establecido la proporción sexos, la longitud y la edad de la primera madurez, el ciclo anual del desarrollo gonadal, el período de freza y la fecundidad de G. vittatus en base a 704 individuos, capturados mediante inmersión con escafandra autónoma en el norte del Adriático (región de Kvarner), desde abril 2001 hasta marzo 2002. La proporción entre sexos por mes no resulta significativamente distinta, excepto durante el período de freza, cuando se observa una marcada desviación a favor de las hembras. La longitud estimada de la primera madurez es de $32.8 \mathrm{~mm}$ y $35.4 \mathrm{~mm}$ para machos y hembras respectivamente. El desarrollo de las gónadas se produce en el primer año de la vida en ambos sexos. Todos los individuos son maduros a los tres años. El período de freza se extiende de abril hasta julio y la fecundidad total va de 560 a 3045 huevos/hembra madura, con una media de1426 \pm 86 . La presencia simultánea de tres tallas diferentes de oocitos en los ovarios maduros indica que la reproducción de esta especie es múltiple.

Palabras clave: Gobiidae, proporción de sexos, madurez, freza, fecundidad.

\section{INTRODUCTION}

With 59 species, Gobiidae is the most specious fish family in the Mediterranean (Kovačić, 2005). Great ecological diversity seen in gobies indicates their value as research material in life-history evolution (Miller, 1984). However, most gobies are not easily collected and the conventional fishing gears are in most cases useless. Detailed studies of reproductive biology of gobiid species based on year- round samples are therefore rare and currently there are no data on reproduction for more than half of the Mediterranean and northeastern Atlantic gobiid species (Kovačić, 2001). Among them, the striped goby, Gobius vittatus Vinciguerra, 1883 was considered to be rare (Tortonese, 1975) or very rare (Jardas, 1985) due to the lack of data. For a long time only morphology and habitat of the striped goby were known from the few papers published since the species description, based on one or two specimens 
(Vinciguerra, 1883; Kolombatović, 1886; 1891; Fage, 1918; De Buen, 1923; Tortonese, 1975). Heymer and Zander (1978) described habitat, diet and morphology on 21 specimens from Banyuls-sur-Mer (France). Some biological aspects of $G$. vittatus were studied in detail in the northern Adriatic Sea, where an abundant population of this species was found in a characteristic ground using SCUBA diving (Kovačić, 2004, 2006, 2007). Goby G. vittatus is a Mediterranean endemic species present on coralline grounds from 20 to $42 \mathrm{~m}$ depth (Heymer and Zander, 1978) and on a mixed bottom of rock and sand, with a steep to medium slope from 5 to $34 \mathrm{~m}$ depth (Kovačić, 2004). It is a small-sized species, with a maximum recorded size of $58 \mathrm{~mm}$ (Heymer and Zander, 1978). It is a carnivore and generalist, feeding on a wide variety of prey items, particularly polychaetes, gastropods, copepods, ostracods and bivalves (Heymer and Zander, 1978; Kovačić, 2004, 2007). Maximum estimated age in the northern Adriatic Sea was 4 and 3 years for females and males, respectively (Kovačić, 2004, 2006). The aim of this paper is to provide the first data on reproduction of $G$. vitattus, including the sex ratio, length and age at first maturity, annual cycle of gonad development, spawning period, relationship of the reproductive cycle and liver storage, fecundity and recruitment of young.

\section{MATERIAL AND METHODS}

Seven hundred and four specimens of G. vittatus were obtained at three locations (Stara voda, Oštro and Selce) in the Kvarner area, northern Adriatic Sea, from April 2001 to March 2002 (Fig. 1). All fish, including the first records of the young recruited to the demersal adult population, were collected between 8 and $20 \mathrm{~m}$ depth, using a hand net and the anaesthetic quinaldine during SCUBA dives. Each month twenty specimens were collected at each location. However, only four specimens were collected in January at Oštro due to bad weather and low temperature. During the SCUBA dives the water temperature was measured at the collecting depth. All specimens were killed by over-anaesthetisation with quinaldine and fixed in $65 \%$ alcohol.

In the laboratory, the total length (TL) of each individual was measured to the nearest $0.1 \mathrm{~mm}$ (they were later grouped into $5 \mathrm{~mm}$ length classes) and wet mass was weighed to the nearest $0.001 \mathrm{~g}$ after blotting dry on absorbent paper. Sagittal otoliths

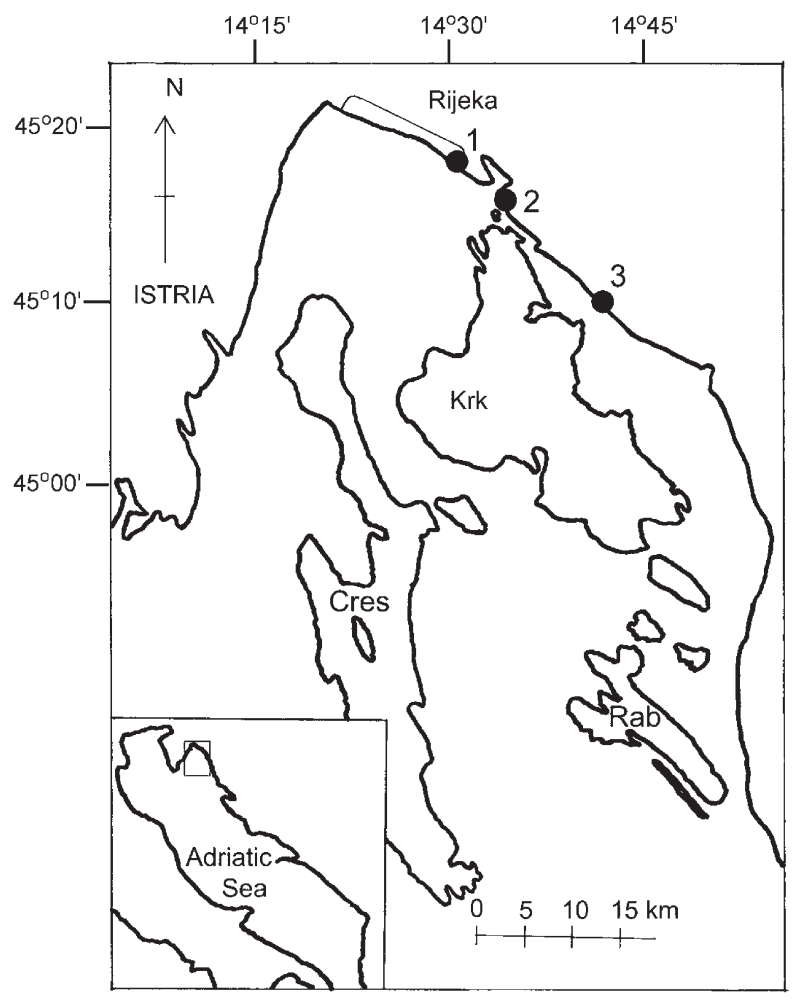

FIG. 1. - The Kvarner area, Croatia. Collecting sites: (1) Stara voda, (2) Oštro and (3) Selce.

were removed and used for ageing purposes, as described in detail in Kovačić (2006). The specimens were dissected under a stereomicroscope and gut, liver and gonads were removed. Sex was recorded and gonads were macroscopically staged according to the gonad development classification for gobies with a five-point scale of maturity: I immature, II - developing virgin and recovering spent, III - ripening (for females IIIa - early ripening and IIIb - late ripening), IV - ripe, V - spent (Miller, 1961). The wet mass of gonads and liver was obtained to the nearest $0.1 \mathrm{mg}$ after blotting dry on absorbent paper. In males all testicular apparatus (testes and seminal vesicles) was weighed as gonad mass. Furthermore, the seminal vesicles were weighed separately (Kovačić, 2001). The running ripe ovaries (stage IV) were used to calculate fecundity. A portion of ovaries was wet weighed and only the ripe oocytes were counted to estimate total fecundity $(\mathrm{F}=$ wet mass of ovaries $\mathrm{x}$ wet mass of counted portion $^{-1} \mathrm{x}$ number of oocytes in portion). Oocyte size was measured as maximum diameter using a micrometric scale.

Sex ratio was calculated monthly and the significance of deviation from 1:1 null hypothesis was tested by $\chi^{2}$ test (Sokal and Rohlf, 1995). The length and 
age at first maturity were estimated by the proportion of mature specimens (i.e. in stages II-V, Miller, 1961). The length at first maturity, defined as the length at which $50 \%$ of fish are mature, was estimated by means of a logistic function fitted to the proportion of the mature specimens pooled in $5 \mathrm{~mm}$ length classes (L). The quasi-Newton algorithm for non-linear least square estimation of function parameters was applied to data according to the following equation: $\mathrm{P}_{\mathrm{L}}$ $=\left(1+\mathrm{e}^{-\mathrm{a}(\mathrm{L}-\mathrm{b})}\right)^{-1}$, where $\mathrm{P}_{\mathrm{L}}$ is the proportion of mature fish at length $\mathrm{L}$; $\mathrm{a}$ and $\mathrm{b}$ are estimated parameters, where $\mathrm{a}$ is the slope of the curve and $\mathrm{b}$ corresponds to a proportion of 0.5 mature fish (Morato et al., 2003). The annual cycle of gonad development was investigated using maturity stages as in Miller (1961) and calculating gonadosomatic index (GSI= gonad wet mass x $100 \mathrm{x}$ body wet mass $^{-1}$ ) and seminal-vesicalsomatic index $($ SVSI $=$ seminal vesicle wet mass $\mathrm{x}$ $100 \mathrm{x}$ body wet mass $^{-1}$ ) (Patzner et al., 1991) on monthly samples. The hepatosomatic index (HSI) was calculated as HSI = liver wet mass $\mathrm{x} 100 \mathrm{x}$ body wet mass ${ }^{-1}$ (Fouda et al., 1993), as a measure proportional to energy reserves stored in this organ. All indices were compared across months using the nonparametric Kruskal-Wallis test, and the HSI was compared between sexes using the Mann-Whitney U-test, since the assumptions of normality and homogeneity were not met after arc-sine or logarithmic transformation (Sokal and Rohlf, 1995). Homogeneity of variance and normality were tested with Levene's test and the Kolmogorov-Smirnov test, respectively. The relationship between total fecundity and fish length was assessed by regression analysis of log-transformed data. Descriptive statistics are reported as mean \pm standard error. A non-linear estimate of logistic function parameters for length at first maturity was calculated using Statistica 5.1. Other data analyses were carried out using the Excel and SPSS software packages.

\section{RESULTS}

\section{Sex ratio}

All 704 specimens of $G$. vittatus were sexed successfully. The overall ratio of males to females was 1:1.33, diverging significantly from $1: 1\left(\chi^{2}=14.2\right.$, d.f. $=1, \mathrm{P}<0.001)$. Monthly sex ratio however, did not differ significantly from $1: 1$, except for the period May to July 2001 (Table 1).
TABLE 1. - Monthly sex ratio of G. vittatus from the Kvarner area (April 2001 to March 2002) tested by $\chi^{2}$ analysis. P, significance level; *, $\mathrm{P}<0.05$.

\begin{tabular}{lcclc}
\hline Month & No. of males & No. of females & Sex ratio & $\mathrm{P}$ \\
\hline Apr 2001 & 24 & 36 & $1: 1.5$ & 0.121 \\
May 2001 & 18 & 42 & $1: 2.33$ & $0.002^{*}$ \\
Jun 2001 & 10 & 50 & $1: 5$ & $<0.001^{*}$ \\
Jul 2001 & 17 & 43 & $1: 2.52$ & $<0.001^{*}$ \\
Aug 2001 & 24 & 36 & $1: 1.5$ & 0.121 \\
Sep 2001 & 30 & 30 & $1: 1$ & 1 \\
Oct 2001 & 27 & 33 & $1: 1.22$ & 0.439 \\
Nov 2001 & 30 & 30 & $1: 1$ & 1 \\
Dec 2001 & 25 & 35 & $1: 1.4$ & 0.197 \\
Jan 2002 & 25 & 19 & $1: 1.3$ & 0.366 \\
Feb 2002 & 37 & 23 & $1: 0.62$ & 0.071 \\
Mar 2002 & 35 & 25 & $1: 0.71$ & 0.197 \\
\hline
\end{tabular}

\section{Length and age at first maturity}

The length at first maturity was estimated on all 402 females, ranging from 20.1 to $54.0 \mathrm{~mm}$, and on all 302 males, ranging from 19.2 to $52.6 \mathrm{~mm}$. Female length at maturity was estimated at 32.8 $\mathrm{mm}$, and male length at maturity at $35.4 \mathrm{~mm}$. The estimates of logistic function parameters for length at first maturity ( $a$ and $b$ ) for females and males are shown in Table 2. Out of 704 specimens examined (402 females and 302 males), 677 specimens (383 females and 294 males) were aged successfully (Kovačić, 2006). In both sexes gonad development started in the first age class $\left(0^{+}\right.$fish: females $35.2 \%$, males $31.3 \%)$. During the second year of life $\left(1^{\circ}\right.$ and $\left.1^{+}\right), 88.9 \%$ of females and $82.4 \%$ of males were mature. In older age groups all specimens were mature.

\section{Annual cycle of gonad development and spawning period}

The proportion of maturity stages for both sexes varied strongly with season (Table 3 ). Female gonadosomatic index (GSI) (Fig. 2a) varied significantly across months $(\mathrm{H}$ Kruskal-Wallis $=279.7, \mathrm{P}<0.001)$,

TABLE 2. - The estimates of parameters ( $a$ and $b$ ) for length at first maturity of logistic function $\mathrm{P}_{\mathrm{L}}=\left(1+\mathrm{e}^{-\mathrm{a}(\mathrm{L}-\mathrm{b})}\right)^{-1}$ for females and males of $G$. vittatus from the Kvarner area $\left(\mathrm{r}^{2}\right.$ coefficient of determination, SE standard error).

\begin{tabular}{lcccl}
\hline \multirow{2}{*}{ Parameter } & \multicolumn{2}{c}{ Females } & \multicolumn{2}{c}{ Males } \\
& Estimate & SE & Estimate & SE \\
& & & & \\
\hline & & & & \\
$\mathrm{a}$ & 0.394 & 0.046 & 0.301 & 0.029 \\
$\mathrm{~b}$ & 32.79 & 0.32 & 35.43 & 0.33 \\
$\mathrm{r}^{2}$ & 0.994 & & 0.995 & \\
\hline
\end{tabular}


(a)

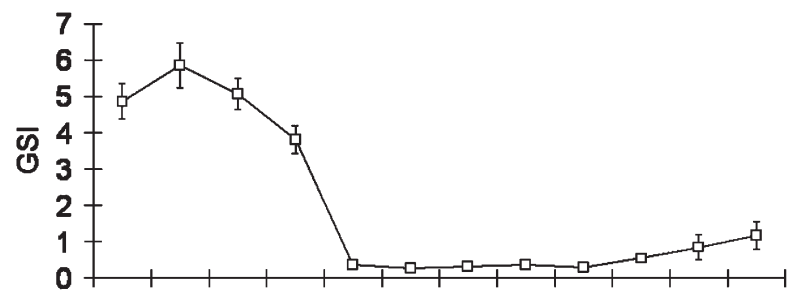

(b)

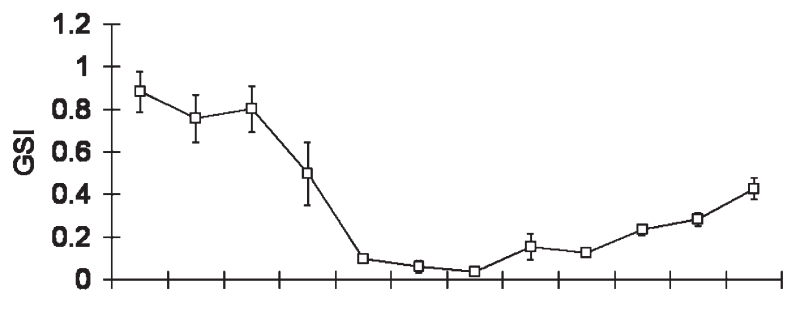

(c)

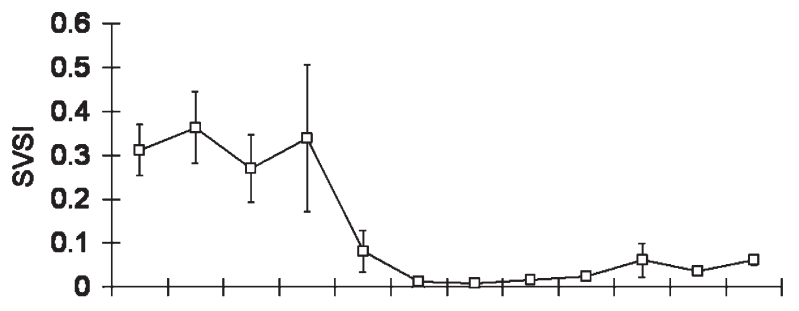

(d)

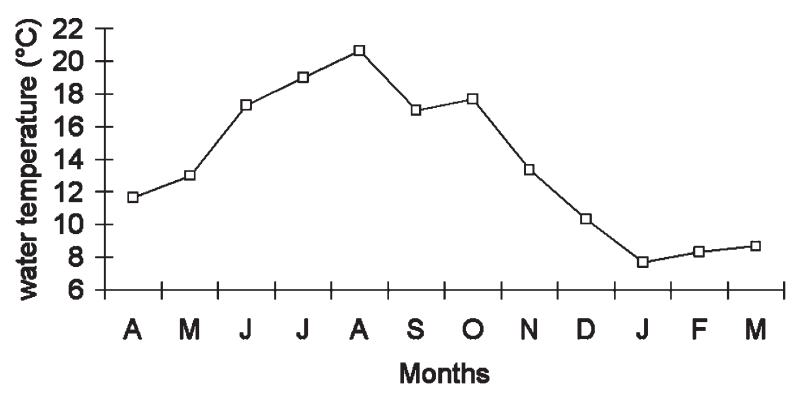

FIG. 2. - Mean ( \pm standard error) monthly gonadosomatic index (GSI) of (a) female and (b) male and the seminal-vesicule-somatic index (SVSI) (c) of G. vittatus from the Kvarner area. Mean monthly sea temperature at the collecting depth (d) is also given.

as did male gonadosomatic index (GSI) (H KruskalWallis $=199.6, \mathrm{P}<0.001)$ and seminal-vesical-somatic index (SVSI) $(\mathrm{H}$ Kruskal-Wallis $=86.7, \mathrm{P}<0.001$ ) (Figs $2 \mathrm{~b}$ and $2 \mathrm{c}$ ). In males all stages indicating gonad development occurred one or two months earlier in the annual cycle than in females. Females and males in stage II (i.e. developing virgin and recovering spent) were mostly found in winter. In this period, female GSI and male SVSI increased slowly, while male GSI showed a steady increase. Ripening males (stage III) were the most numerous in early spring, while ripening females were numerous throughout the entire spring. By April male GSI $(0.88 \pm 0.10)$ and by May female GSI $(5.86 \pm 0.62)$ and male SVSI $(0.36 \pm 0.08)$ were at their maximum and remained high through to July. Ripe males (stage IV) were already present in March. However, the spawning season lasted from April to July, when ripening fish (stage IV) of both sexes were present and all gonad indices were high. In the post-spawning period (from August to November) GSI and SVSI reached their lowest value, and mostly spent (stage V) and immature (stage I) specimens were present. The late pre-spawning and spawning period occurred during an increase in the sea water temperature (Table 3 and Fig. 2).

\section{Hepatosomatic index}

Hepatosomatic indices (HSI) of females (1.96 \pm $0.05)$ and males $(1.77 \pm 0.05)$ were not significantly different (Mann-Whitney U-test, $\mathrm{Z}=1.87, \mathrm{P}>0.05$ ). HSI of both sexes showed a clear seasonal pattern, evidencing significant variation across months (females: H Kruskal-Wallis $=87.7, \mathrm{P}<0.001$; males: $\mathrm{H}$ Kruskal-Wallis $=54.7, \mathrm{P}<0.001)($ Figs $3 \mathrm{a}$ and $3 \mathrm{~b})$. Female HSI $(2.51 \pm 0.14)$ and male HSI $(2.20 \pm$ 0.16) peaked in April. The hepatosomatic index of both sexes decreased during the spawning season from April to July, when female HSI reached the

(a)

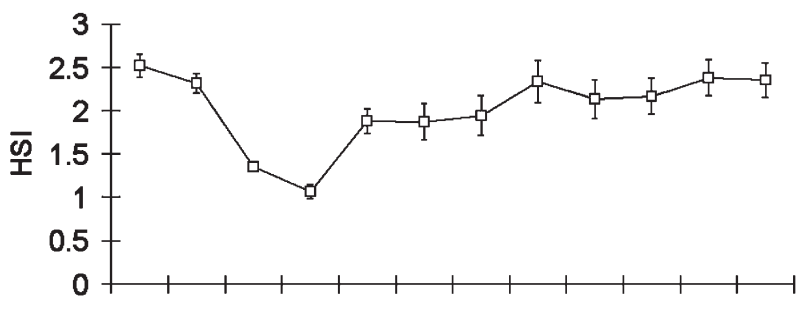

(b)

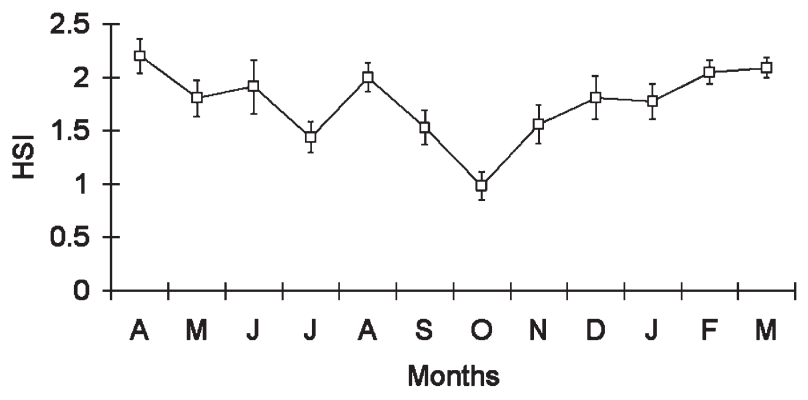

FIG. 3. - Mean ( \pm standard error) monthly hepatosomatic index (HSI) of (a) female and (b) male of G. vittatus from the Kvarner area. 
TABLE 3. - The number of females and males of $G$. vittatus from the Kvarner area in each maturity stages by month: I - immature, II - developing virgin and recovering spent, III - ripening (for females IIIa - early ripening and IIIb - late ripening), IV - ripe, V - spent. In parentheses: number of females and males of maturity stages II-V in proportion to total number of mature females and males for each month.

\begin{tabular}{|c|c|c|c|c|c|c|}
\hline Females & I & II & $\begin{array}{l}\text { Maturity stages } \\
\text { IIIa }\end{array}$ & IIIb & IV & V \\
\hline Apr 2001 & - & $2(5.6 \%)$ & $9(25.0 \%)$ & $15(41.7 \%)$ & $10(27.8 \%)$ & - \\
\hline May 2001 & - & - & $13(31.0 \%)$ & $18(42.9 \%)$ & $10(23.8 \%)$ & $1(2.4 \%)$ \\
\hline Jun 2001 & - & $5(10.0 \%)$ & $10(20.0 \%)$ & $21(42.0 \%)$ & $13(26.0 \%)$ & $1(2.0 \%)$ \\
\hline Jul 2001 & 6 & $3(8.1 \%)$ & $8(21.6 \%)$ & $14(37.8 \%)$ & $12(32.4 \%)$ & - \\
\hline Aug 2001 & 11 & $1(4.0 \%)$ & - & $1(4.0 \%)$ & - & $23(92.0 \%)$ \\
\hline Sep 2001 & 12 & - & - & - & - & $18(100.0 \%)$ \\
\hline Oct 2001 & 17 & $1(6.3 \%)$ & - & - & - & $15(93.8 \%)$ \\
\hline Nov 2001 & 13 & - & - & - & - & $17(100.0 \%)$ \\
\hline Dec 2001 & 17 & $8(44.4 \%)$ & - & - & - & $10(55.6 \%)$ \\
\hline Jan 2002 & 10 & $9(100.0 \%)$ & - & - & - & - \\
\hline Feb 2002 & 8 & $13(86.7 \%)$ & $2(13.3 \%)$ & - & - & - \\
\hline Mar 2002 & 3 & $11(50.0 \%)$ & $6(27.3 \%)$ & $5(22.7 \%)$ & - & - \\
\hline Males & I & II & III & IV & V & \\
\hline Apr 2001 & 2 & $3(13.6 \%)$ & $12(54.5 \%)$ & $7(31.8 \%)$ & - & \\
\hline May 2001 & 1 & $5(29.4 \%)$ & $6(35.3 \%)$ & $6(35.3 \%)$ & - & \\
\hline Jun 2001 & 1 & - & $2(22.2 \%)$ & $7(77.8 \%)$ & - & \\
\hline Jul 2001 & 7 & - & $5(50.0 \%)$ & $2(20.0 \%)$ & $3(30.0 \%)$ & \\
\hline Aug 2001 & 9 & $1(6.7 \%)$ & - & $2(13.3 \%)$ & $12(80.0 \%)$ & \\
\hline Sep 2001 & 18 & - & - & - & $12(100.0 \%)$ & \\
\hline Oct 2001 & 19 & $2(25.0 \%)$ & - & - & $6(75.0 \%)$ & \\
\hline Nov 2001 & 18 & $4(33.3 \%)$ & - & - & $8(66.7 \%)$ & \\
\hline Dec 2001 & 10 & $12(80.0 \%)$ & $3(20.0 \%)$ & - & - & \\
\hline Jan 2002 & 12 & $7(53.8 \%)$ & $6(46.2 \%)$ & - & - & \\
\hline Feb 2002 & 22 & $8(53.3 \%)$ & $7(46.7 \%)$ & - & - & \\
\hline Mar 2002 & 9 & $16(61.5 \%)$ & $6(23.1 \%)$ & $4(15.4 \%)$ & - & \\
\hline
\end{tabular}

lowest value, followed by a continuous recovery until the beginning of the next spawning season. On the other hand, male HSI showed a new decrease from August to October, when it reached the lowest value, followed by a steady increase until the next spawning season.

\section{Fecundity and egg size}

Fecundity was estimated on 45 ripe females from 36.9 to $53.6 \mathrm{~mm}$ TL. The total fecundity ranged from 560 to 3045 , with an average of $1426 \pm 89$ ripe eggs/fish. There was a significant positive relationship between fecundity and fish length $(\mathrm{F}=76.2$, $\mathrm{P}<0.001$ ) (Fig. 4). The regression model between total fecundity and total length was:

$$
\ln \mathrm{F}=3.172 \ln \mathrm{TL}-4.995
$$

However, considerable variability in fecundity of females of similar length was present and the proportion of the variance of fecundity explained by length was not high (coefficient of determination $\mathrm{r}^{2}=0.64$ ).

The measurements of the oocyte diameters showed that a ripe ovary contained fully ripe

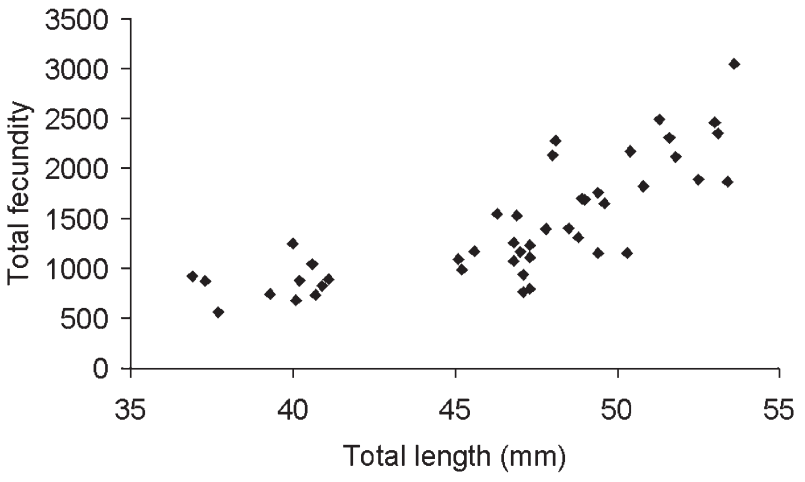

FIG. 4. - Plots of total fecundity against total length of G. vittatus from the Kvarner area.

oocytes $(0.44-0.60 \mathrm{~mm})$, early ripening oocytes $(0.16-0.24 \mathrm{~mm})$ and numerous, very small ones $(<0.08 \mathrm{~mm})$. The presence of three clearly distinct sizes of oocytes in ripe ovaries indicated that each female could spawn at least twice during the breeding season.

\section{Recruitment of young}

The young of the striped goby recruited to the demersal adult population were first found in August 
2001. Total length of eleven specimens ranged from 19.2 to $24.8 \mathrm{~mm}$, with an average of $21.6 \pm 0.6 \mathrm{~mm}$.

\section{DISCUSSION}

The reproductive biology of G. vittatus has never been investigated before the present study. The present data can be compared with those of closely related Gobius species. The sex ratio was strongly biased in favour of females for the period May to July 2001, which coincides with the observed spawning season. The prevalence of females observed during the spawning period was probably due to a decrease in the availability of males. Indeed, during the spawning period males of most gobiid species guard nests, so they are hardly caught at all. The predominately female sex ratio during the spawning season, as a probable result of the cryptobenthic behaviour of males, was also found in Gobius niger (Nash, 1984; Silva and Gordo, 1997). Nash (1984), as well as the present study, found no significant differences in the number of males and females of G. niger out of the spawning period, whereas Silva and Gordo (1997) noted a significant dominance of males for the same species. Hence, data which do not refer to the spawning period provide a more realistic evaluation of sex ratio in populations of most gobiid species featuring nest guarding behaviour.

Similarly to G. niger (Fabi and Froglia, 1984; Vesey and Langford, 1985; Joyeux et al., 1991), G. vittatus manifests early maturation, starting gonad development in the first year of life. In other Gobius species, such as G.paganellus and G. roulei, gonad development starts in the second year of life (Miller, 1961; Kovačić, 2001). However, all these species show late maturation in comparison with short lifespan gobiid species such as Pomatoschistus spp., whose populations are fully mature during the first year of life (Miller, 1961; Gibson and Ezzi, 1981; Bouchereau et al., 1989, 1993).

The spawning period similar to that of G. vittatus, from April to August, has also been observed in $G$. roulei from the Kvarner area and G. niger from the central Adriatic Sea (Fabi and Froglia, 1984; Kovačić, 2001). All Gobius species of the northeast Atlantic and the Mediterranean breed during spring and summer, with a breeding season of two to six months (Miller, 1961; Gibson, 1970; Vaas et al., 1975; Dunne, 1978; Nash, 1984; Vesey and Langford, 1985; Joyeux et al., 1991, 1992; Arruda et al., 1993; Silva and Gordo, 1997; Azevedo and Simas, 2000). Nevertheless, the spawning season of Gobius species in the northeast Atlantic usually begins earlier and is shorter than in the Mediterranean. At higher latitudes, limitation of productivity to short periods of the year cannot support a long season of repeat-spawning of species originated under warmer conditions (Miller, 1979).

Closely linked with reproduction is phenology of storage (Miller, 1979). Annual variations in liver mass could reflect the process of storage and transfer of energy from periods of intensive feeding to periods of restricted feeding but high energy demands. The data on the relationship of the liver storage and the reproductive cycle of gobies are rare (Miller, 1984; Joyeux et al., 1992; Fouda et al., 1993). These data, as well as the present study, show that liver plays an important role in storage during the annual cycle of gonad development. A marked reduction in liver mass was noticed at the beginning of or during the breeding season (Joyeux et al., 1992; Fouda et al., 1993).

The size frequency of oocytes within mature ovary of Gobius species shows that they are repeat spawners, like the majority of gobies (Miller, 1984). The total fecundity estimated on ripe oocytes therefore represents the batch fecundity and not the annual fecundity. The fecundity of the striped goby is generally lower than in other Gobius species such as G. cobitis, G. paganellus and G. roulei (Miller, 1961; Gibson, 1970; Dunne, 1978; Kovačić, 2001). The ripe oocytes of $G$. vittatus were similar in size to those of G. roulei (Kovačić, 2001), but smaller than those of other, larger Gobius species, which measure more than $1 \mathrm{~mm}$ in diameter (Miller, 1961; Gibson, 1970). Among Gobius species, fecundity and egg size generally depended on species size. In addition, the reduction of egg size in smaller species slows down the decrease of fecundity linked to a decrease in body and ovarian mass. The estimation of number of egg batches laid by Gobius species during the spawning season is only known for $G$. paganellus, which spawned twice per season (Miller, 1984). With G. vittatus the number of oocyte classes found in the ripe ovaries does not necessarily reflect the number of batches produced during one season, because of possible recruitment from numerous immature oocytes. Multiple spawning and the parental care may increase the reproductive success in the striped goby and compensate for the relatively low fecundity. 
The young of G.paganellus recruited to the demersal adult population were first found four months after the beginning of the spawning season (Miller, 1961) and four months after the GSI reached maximum values (Azevedo and Simas, 2000), similarly to the present results on the striped goby.

The striped goby is the smallest Gobius species. Considering the data already published, it shares characteristics of reproductive biology with congenerics. Small size, compared to other Gobius species, resulted in a relatively early maturation, low fecundity and small egg size.

\section{ACKNOWLEDGEMENTS}

I am grateful to M. La Mesa for criticism and comments on this paper and to S. Padavić for the improvement of language and style. Diving assistance was provided by M. Arko-Pijevac.

\section{REFERENCES}

Azevedo, J.M.N and A.M.V. Simas. - 2000. Age and growth, reproduction and diet of a sublittoral population of the rock goby Gobius paganellus (Teleostei, Gobiidae). Hydrobiol., 440: 129-135.

Borges R., C. Faria, F. Gil, E.J. Gonçavles and V.C. Almada. 2003. Embryonic and larval development of Gobius paganellus (Pisces: Gobiidae). J. Mar. Biol. Ass. UK, 83: 1151-1156.

Bouchereau, J.-L., J.-C. Joyeux, J.-A. Tomasini and J.-P. Quignard. - 1989. Cycle sexuel, fécondités et condition de Pomatoschistus microps (Krojer, 1838) (Gobiidés) dans la lagune de Mauguio- France. Bull. Ecol., 20(3): 193-202.

Bouchereau, J.-L., J.-P. Quignard, J.-C. Joyeux and J.-A. Tomasini. - 1993. Structure du stock des géniteurs de la population de Pomatoschistus microps (Krojer, 1838) (Gobiidae) dans la lagune de Mauguio, France. Cybium, 17(1): 3-15.

De Buen, F. - 1923. Gobius de la Peninsula Iberica y Baleares. Groupos Lesueurii, Colonianus, Affinis y Minutus. Mem. Inst. Esp. Oceanogr., 3: 121-266.

Dunne, J. - 1978. Littoral and benthic investigations on the west coast of Ireland - IX (Section A: Faunistic and ecological studies). The biology of the rock-goby, Gobius paganellus L., at Carna. Proc. Royal Irish Acad., 78B(12): 179-191.

Fabi, G. and C. Froglia. - 1984. A note on the biology and fishery of the black goby (Gobius niger) in the Adriatic Sea. FAO Fish. Rep., 290: 167-170.

Fage, L. - 1918. Shore-fishes. Rep. Dan. oceanogr. Exped. Med., 2(A3): 1-154.

Fouda, M.M., M.Y. Hanna and F.M. Fouda. - 1993. Reproductive biology of the Red Sea goby, Silhouettea aegyptia, and a Mediterranean goby, Pomatoschistus marmoratus, in Lake Timsah, Suez Canal. J. Fish. Biol., 43: 139-151.

Gibson, R.N. - 1970. Observations on the biology of the giant goby Gobius cobitis Pallas. J. Fish. Biol., 2: 281-288.

Gibson, R.N. and I.A. Ezzi. - 1981. The biology of Norway goby, Pomatoschistus norvegicus (Collett), on the west coast of Scotland. J. Fish. Biol., 19: 697-714.
Gil, M.F., E.J. Gonçavles, C. Faria, V.C. Almada, C. Baptista and H. Carreiro. - 1997. Embryonic and larval development of the giant goby Gobius cobitis (Pisces: Gobiidae). J. Nat. Hist., 31: 799-804.

Heymer A. and C.D. Zander. - 1978. Morphology and ecology of Gobius vittatus Vinciguerra, 1883, and its possible mimicry relationship to Blennius rouxi Cocco, 1833 in the Mediterranean. Z. Zool. Syst. Evol., 16: 132-143.

Jardas, I. - 1985. Pregled riba (sensu lato) Jadranskog mora (Cyclostomata, Selachii, Osteichthyes) s obzirom na taksomoniju i utvrdeni broj. Biosist., 11(1): 45-74.

Joyeux, J.-C., J.-L. Bouchereau and J.-A. Tomasini. - 1991. La reproduction de Gobius niger (Pisces, Gobiidae) dans la lagune de Mauguio - France. Vie Milieu, 41: 97-106.

Joyeux, J.-C., J.-A. Tomasini and J.-L. Bouchereau - 1992. Modalités de la reproduction de Gobius niger (Teleostei, Gobiidae) dans une lagune Méditerranéenne. Vie Milieu, 42: 1-13.

Kolombatović, J. - 1886. Imenik kralješnjaka Dalmacije II dio: Dvoživci, gmazovi i ribe. Godišnje izvješće C. K. Velike realke u Splitu za školsku godinu, 1885/86: 2-32.

Kolombatović, J. - 1891. Glamoči (Gobii) Spljetskog Pomorskog Okružja. Godišnje izvješće C. K. Velike realke u Splitu za školsku godinu, 1890-91: 1-29.

Kovačić, M. - 2001. The biology of Roule's goby in the Kvarner area, northern Adriatic Sea. J. Fish Biol., 59(4): 795-809.

Kovačić, M. - 2004. Biološka i ekološka obiljel̈ja vrste Gobius vittatus (Gobiidae, Pisces) u Jadranskom moru. Ph. D. thesis, Univ. Zagreb.

Kovačić, M. - 2005. An annotated checklist of the family Gobiidae in the Adriatic Sea. Annales Series Historia Naturalis, 15: 21-44.

Kovačić, M. - 2006. Age structure, mortality and growth of the striped goby, Gobius vittatus (Gobiidae) in the northern Adriatic Sea. Sci. Mar., 70: 635-641.

Kovačić, M. - 2007. Diet of Gobius vittatus (Gobiidae) in the northern Adriatic Sea. Vie Milieu, in press.

Miller, P.J. - 1961. Age, growth, and reproduction of the rock goby Gobius paganellus L., in the Isle of Man. J. Mar. Biol. Ass. U.K., 41: 737-769.

Miller, P.J. - 1979. Adaptiveness and implications of small size in teleosts. Symp. Zool. Soc. Lond., 44: 263-306.

Miller, P.J. - 1984. The tokology of gobioid fishes. In: H.W. Potts and R.J. Wootton (eds.), Fish reproduction / Strategies and tactics, pp. 119-153. Academic press, London.

Morato, T., P. Afonso, P. Lourinho, R.D.M. Nash and R.S. Santos. - 2003. Reproductive biology and recruitment of the white sea bream in the Azores. J. Fish. Biol. 63: 59-72.

Nash, R.D.M. - 1984. Aspects of the biology of the black goby, Gobius niger L., in Oslofjorden, Norway. Sarsia, 69: 55-61.

Patzner, R.A., M. Seiwald, S. Angerer, E.A. Ferrero and P.G. Giulianini. - 1991. Genital system and reproductive cycle of the male grass goby, Zosterisessor ophiocephalus (Teleostei, Gobiidae) in the Northern Adriatic Sea. Zool. Anz., 226(5/6): 205-219.

Silva, M.N. and L.S. Gordo. - 1997. Age, growth and reproduction of the black goby, Gobius niger, from Óbidos Lagoon, Portugal. Cah. Biol. Mar., 38: 175-180.

Sokal, R.R and F.J. Rohlf. - 1995. Biometry. W. H. Freeman and company, New York.

Tortonese, E. - 1975. Osteichthyes (Pesci ossei), Parte seconda. Fauna d'Italia, Vol. 11. Calderini, Bologna.

Vaas, K.F., A.G. Vlasblom and P. Koeijer. - 1975. Studies on the black goby (Gobius niger, Gobiidae, Pisces) in the Veerse Meer, SW Netherlands. Neth. J. Sea Res., 9: 56-68.

Vesey G. and T.E. Langford. - 1985. The biology of the black goby, Gobius niger L. in an English south-coast bay. J. Fish Biol., 27: 417-429.

Vinciguerra, D. - 1883: Resultati ittiologici della crociere del «Violante». Annali Mus. civ. Stor. nat., Genova, 18: 465-590.

Scient. ed.: A. Garcia-Rubies.

Received June 29, 2006. November 27, 2006.

Published online February 26, 2007. 
